Paper:

\title{
Point-Based Rainfall Intensity Information System in Mt. Merapi Area by X-Band Radar
}

\author{
Santosa Sandy Putra ${ }^{* 1, * 2, \dagger}$, Banata Wachid Ridwan ${ }^{* 1}$, Kazuki Yamanoi ${ }^{* 3}$, \\ Makoto Shimomura $^{* 4}$, Sulistiyani ${ }^{* 5}$, and Dicky Hadiyuwono ${ }^{* 6}$ \\ ${ }^{* 1}$ Balai Sabo, Ministry of Public Works and Housing \\ Balai Sabo, Sopalan, Maguwoharjo, Yogyakarta 55282, Indonesia \\ ${ }^{\dagger}$ Corresponding author, E-mail: santosa-sp@mail.ugm.ac.id \\ ${ }^{* 2}$ School of Geography, Faculty of Environment, University of Leeds, Leeds, United Kingdom \\ ${ }^{* 3}$ RIKEN Center for Computational Science, Kobe, Japan \\ ${ }^{* 4}$ Sakurajima Volcano Research Center, Kyoto University, Kagoshima, Japan \\ ${ }^{*}$ Balai Penyelidikan dan Pengembangan Teknologi Kebencanaan Geologi, Ministry of Energy and Mineral Resources, Yogyakarta, Indonesia \\ ${ }^{* 6}$ Department of Civil and Environmental Engineering, Universitas Gadjah Mada, Yogyakarta, Indonesia \\ [Received July 30, 2018; accepted December 19, 2018]
}

An X-band radar was installed in 2014 at Merapi Museum, Yogyakarta, Indonesia, to monitor pyroclastic and rainfall events around Mt. Merapi. This research aims to perform a reliability analysis of the point extracted rainfall data from the aforementioned newly installed radar to improve the performance of the warning system in the future. The radar data was compared with the monitored rain gauge data from Balai Sabo and the IMERG satellite data from NASA and JAXA (The Integrated Multi-satellitE Retrievals for GPM), which had not been done before. All of the rainfall data was compared on an hourly interval. The comparisons were conducted based on 11 locations that correspond to the ground rainfall measurement stations. The locations of the rain gauges are spread around Mt. Merapi area. The point rainfall information was extracted from the radar data grid and the satellite data grid, which were compared with the rain gauge data. The data were then calibrated and adjusted up to the optimum state. Based on January 2017-March 2018 data, it was obtained that the optimum state has a NSF value of 0.41 and $R^{2}$ value of 0.56. As a result, it was determined that the radar can capture around $79 \%$ of the hourly rainfall occurrence around Mt. Merapi area during the chosen calibration period, in comparison with the rain gauge data. The radar was also able to capture nearby $40-50 \%$ of the heavy rainfall events that pose risks of lahar. In contrast, the radar data performance in detecting drizzling and light rain types were quite precise (55\% of cases), although the satellite data could detect slightly better $(60 \%$ of cases). These results indicate that the radar sensitivity in detecting the extreme rainfall events must receive higher priority in future developments, especially for applications to the existing Mt. Merapi lahar early warning systems.
Keywords: point-based, rainfall, lahar, Mt. Merapi, X-band radar

\section{Introduction}

The history of rainfall radar monitoring in Mt. Merapi, Java, Indonesia started in 1984, when the first instrument was installed as a collaboration project between the Japan International Cooperation Agency (JICA) and Indonesian Ministry of Public Works [1]. Later, the Sabo Technical Centre (Balai Sabo) that is responsible for maintaining the system installed a newer version of the rainfall radar in 2011. This radar was installed after the 2010 Mt. Merapi eruption with the aim of providing early warning of lahar flow, which was highly likely to occur during that period [2]. This effort was continued by the SATREPS Integrated Study on Mitigation of Multimodal Disasters Research Consortium with the installation of an X-band radar in 2014. Furthermore, there is other implementation of radar, which is used as a tool for a weather and meteorological monitoring system. There are 41 established weather radar equipment over the Indonesian archipelago until 2017 [3]. This achievement was initiated also by cooperation between the Japanese and Indonesian governments within the Hydrometeorological ARray for IsvMonsoon AUtomonitoring (HARIMAU) radar monitoring networks [4]. The HARIMAU system also covers some parts of the area around Mt. Merapi.

Rainfall radar is typically used when the ground rain gauge data cannot be quickly transferred to the monitoring office during a heavy rainfall event [5]. Radar can detect rainfall events at a higher temporal resolution of up to $60 \mathrm{~s}$ measurement interval $[5,6]$. Radar rainfall data are commonly used as bases for validating weather forecast models because they contain not only rainfall intensities, but also rainfall distribution profiles [7]. However, the X-band radar installed at Mt. Merapi has not been suf- 


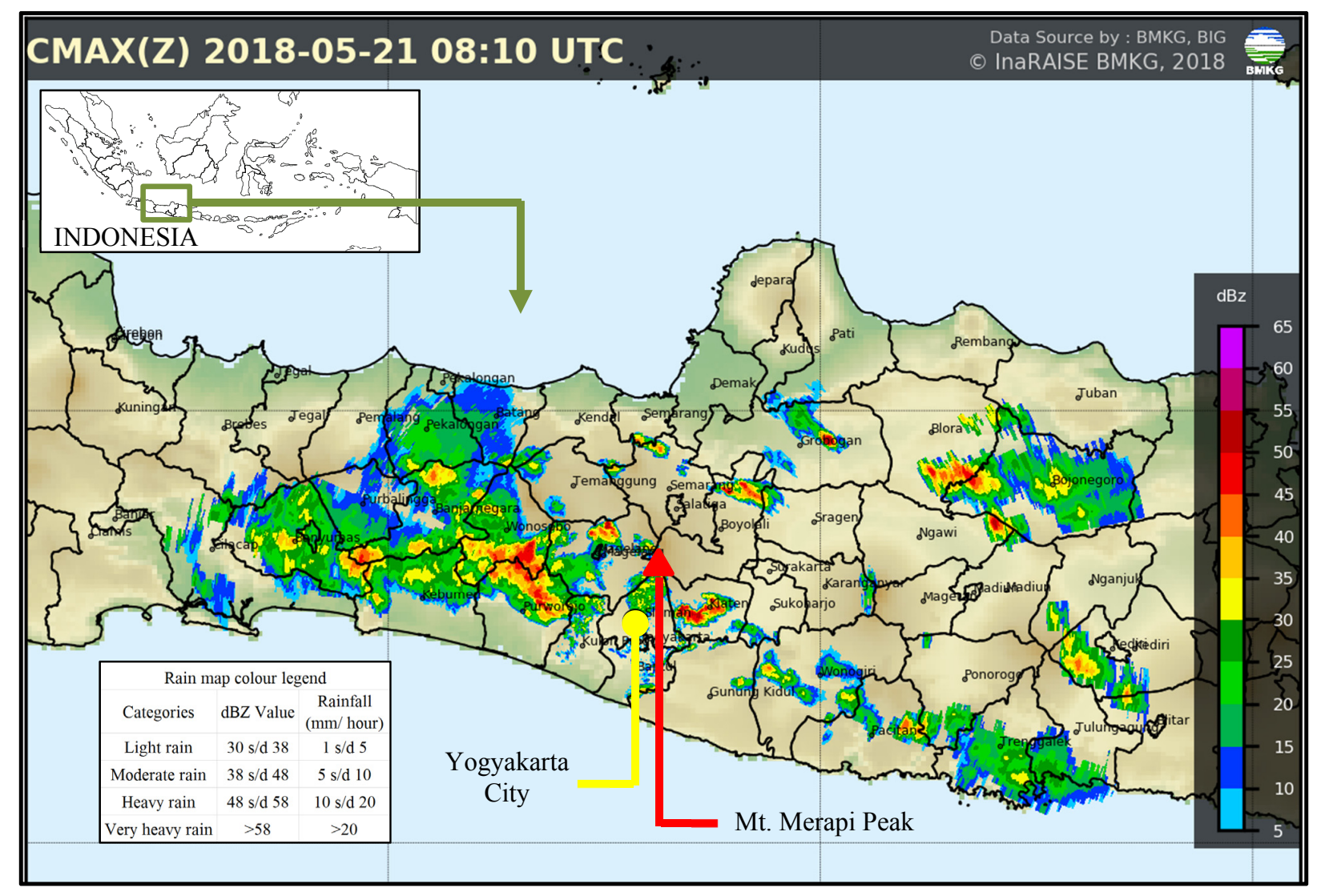

Source: InaRAISE BMKG-BIG [9] and Indonesia Blank Map [10]

Fig. 1. Publicly accessible radar data based rainfall map.

ficiently calibrated with point rain gauge data to support applications for lahar early warning.

An operational lahar early warning system needs near real-time rainfall intensity data input, which cannot be supplied by rain gauges [8]. It is because the rain gauge telemetry system may not function during disasters, as was the case when the system was broken due to the 2010 Mt. Merapi eruption [2]. Nowadays, researchers started to explore the applicability of radar data for early warning system, although radar data are still generally low-resolution $[5,6]$. The radar data provided by the Indonesian Meteorological, Climatological, and Geophysical Agency (BMKG), as presented in Fig. 1, has a resolution of $100 \mathrm{~m} \times 100 \mathrm{~m}$ [4]. The installed X-band radar at Mt. Merapi has a resolution of $150 \mathrm{~m} \times 150 \mathrm{~m}$.

This research explores rainfall radar data reliability for lahar early warning application. The reliability analyses were performed based on a comparison of point extracted rainfall data to rain gauge point rainfall data. The point intensity approach was adopted because of the limitation in rain gauge data continuity and availability around Mt. Merapi area [11, 12]. This restriction might limit rainfall duration and rainfall aerial extent reliability analyses to be conducted at this time (more details in Section 3). The novelty of this research is in relating rainfall radar data reliability with lahar risk classification framework that is presently being used in Mt. Merapi area. The originality of this research is embedded in the radar data adjustment mechanism, the use of a multi-station reliability analysis approach, and the implementation of the new lahar early warning system. This research will promote a significant insights into how radar data must be preprocessed for the lahar early warning system. This research will highlight the importance of rain gauge station distribution for future continuous radar calibration. Furthermore, this paper will also identify the practical impact of using point extracted rainfall radar for lahar early warning system in Mt. Merapi area. Such a system can be used in conjunction with the telemetry-based lahar early warning system presented by Cobar et al. [8].

\section{Methodology}

The rainfall radar data reliability research was done for the Mt. Merapi area case study, with the radar and rain gauge data between 2017 and 2018. The point-based rainfall data were extracted from both radar and satellite spatial rainfall data based on the rain gauges location coordinate. The point rainfall radar data then tested for its reliability by comparing it against the point rain gauge data and the point rainfall satellite data. The use of point 


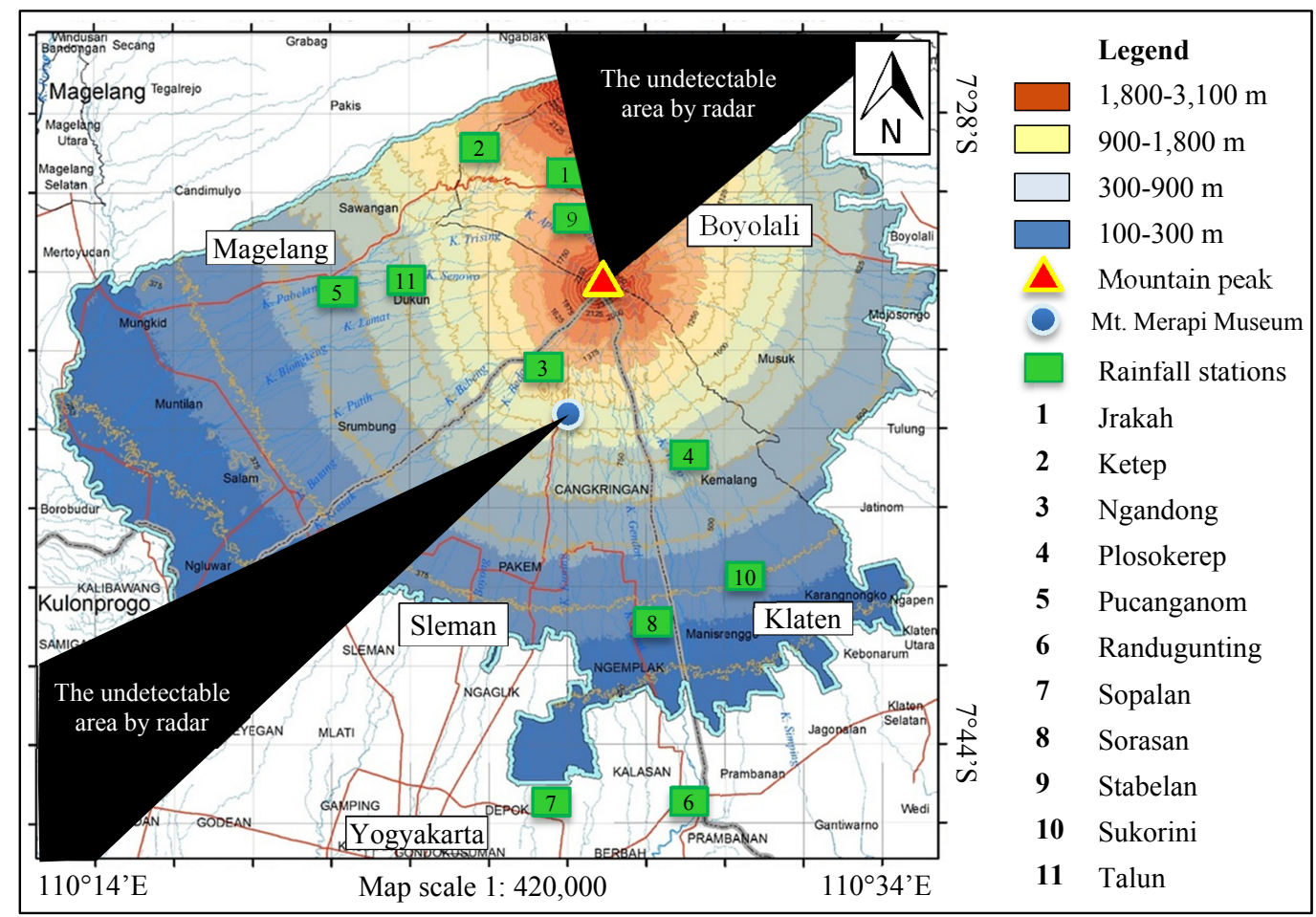

This map was created by Balai Sabo, based on Rupa Bumi Indonesia Map 2013 from Indonesian Geospatial Information Agency.

Fig. 2. Distribution of ground rainfall monitoring station around Mt. Merapi area.

extracted radar data method is novel, in comparison with existing telemetry system in Mt. Merapi [8]. Detail analyses were conducted for each rainfall classification. Each rainfall class has its specific lahar risk attributes.

\subsection{Location and Data}

The studied radar is located at Mt. Merapi Museum, Yogyakarta, Indonesia, with the coordinate of $7^{\circ} 36^{\prime} 58.3^{\prime \prime} \mathrm{S}$ and $110^{\circ} 25^{\prime} 27.6^{\prime \prime} \mathrm{E}$. The radar monitored coverage area ranges between $7^{\circ} 54^{\prime} 58.2^{\prime \prime} \mathrm{S}$ and $110^{\circ} 07^{\prime} 27.5^{\prime \prime} \mathrm{E}$ up to $7^{\circ} 18^{\prime} 58.2^{\prime \prime} \mathrm{S}$ and $110^{\circ} 43^{\prime} 27.5^{\prime \prime} \mathrm{E}$ (Fig. 2). These area covers most part of Mt. Merapi vicinities, which are Yogyakarta City, Sleman Regency, Magelang City, the eastern part of Magelang Regency, the western part of Boyolali Regency, Klaten Regency, the northern part of Bantul Regency, and the eastern part of Kulon Progo Regency. Unfortunately, there are two undetectable area, which are in the southwesterly direction from the radar and in the north northeast of Mt. Merapi peak. This is because the radar signals are blocked by the mountain and some identified object on the museum roof.

The installed X-band radar is a Doppler MultiParameter (MP) Radar that does not perform the polarization function. However, instead of rainfall intensity information, the radar can still detect wind state [13] and volcanic ash distribution $[14,15]$. In this research, the analysis focused on the rainfall data rather than the volcanic ash data. The radar can detect rainfall within a radius of $60 \mathrm{~km}$ with a set data interval of five minutes. The data processing time and data transfer time to the monitoring station in BPPTKG office, Yogyakarta, are considered in each data interval. The radar data are available in raster format with a grid size of $150 \mathrm{~m} \times 150 \mathrm{~m}$. Each grid represents the average rainfall over a $2.25 \times 10^{4} \mathrm{~m}^{2}$ area. The detailed specification of the installed X-band radar is published on the official product website $[16,17]$.

The rainfall data that was compared with the radar data were the ground station rain gauge data and the Integrated Multi-satellitE Retrievals for GPM (IMERG) satellite data. The rain gauge data were provided by Balai Sabo for the period January 2017-March 2018. The rain gauge data were sets of point measured rainfall data at an hourly interval. The distribution of the rain gauge stations that were used in this research are shown in Fig. 2. Meanwhile, the IMERG data were half-hourly spatial rainfall data with $0.1^{\circ} \times 0.1^{\circ}$ grid size unit in coverage [18], over an area of approximately $12.35 \times 10^{9} \mathrm{~m}^{2}$. The Global Precipitation Measurement (GPM) is an international satellite mission for rainfall and snow monitoring that is maintained by NASA and JAXA [19].

The map area presented in Fig. $\mathbf{2}$ is within the rainfall radar monitoring range. Meanwhile, the rainfall radar is installed mainly for lahar early warning purposes. The coverage area of the radar is therefore focused on the source and transportation area of lahar. Generally, lahar in volcanic areas are initiated in areas with river bed slope exceeding $15^{\circ}$ and usually transported in the area with river bed slope exceeding $10^{\circ}$ [20]. In the case of 
Mt. Merapi, these areas are located $300 \mathrm{~m}$ above mean sea level (the colored areas in Fig. 2). There are 11 monitoring stations that are maintained by Balai Sabo that mainly record the point ground rainfall in hourly intervals. The ground station rainfall data were used as benchmark for reliability analysis as it had been used in the telemetrybased lahar warning system [8]. In many studies, rain gauge data were used as point of references, in spite of their possible embedded uncertainty [14, 21, 22].

\subsection{Methods}

The data analyses were performed on the BPPTKG and Balai Sabo servers. The BPPTKG server performed the radar data analysis to produce the rainfall raster file in GeoTIFF raster format. The BPPTKG server also received the radar data from the radar computer in Mt. Merapi Museum. The raw rainfall radar data were adjusted, since the radar initially detects rainfall in wave reflection intensity units [dBZ] $[14,16]$. The BPPTKG transformed the rainfall reflectivity data in $[\mathrm{dBZ}]$ to rainfall intensity data in $[\mathrm{mm} / \mathrm{h}]$. The Balai Sabo Server downloaded and adjusted the GeoTIFF rainfall data from the BPPTKG server as inputs for the point rainfall reliability analysis. The reason for adjusting the radar data, which is crucial for radar data applicability, is described in Section 3.

Meanwhile, the point data were extracted from the spatial raster data, which are the radar and satellite data, based on the rain gauge station coordinate. Since the data were not in hourly interval, the data had to be aggregated. The radar data were aggregated from 5-minute interval data to hourly data, while the satellite data were aggregated from half-hourly interval data into hourly data. The rain gauge data that were used as benchmark were recorded at hourly intervals already. Correlation analyses were conducted to calculate the coefficient of determination $\left(R^{2}\right.$ in Eq. (1)) and the Nash-Sutcliffe efficiency (NSF in Eq. (2)). The $R^{2}$ index was used to determine the linear distribution between the compared data, whereas the intensity difference were determined by the NSF equation, as follows:

$$
\begin{gathered}
R^{2}=\left(\frac{\sum_{t=1}^{T}\left(P_{c}{ }^{t}-\bar{P}_{c}\right)\left(P_{r}{ }^{t}-\bar{P}_{r}\right)}{\left(\sum_{t=1}^{T}\left(P_{c}{ }^{t}-\bar{P}_{c}\right)^{2}\right)^{0.5}\left(\sum_{t=1}^{T}\left(P_{r}{ }^{t}-\bar{P}_{r}\right)^{2}\right)^{0.5}}\right)^{2} \\
\mathrm{NSF}=1-\frac{\sum_{\mathrm{t}=1}^{\mathrm{T}}\left(\mathrm{P}_{\mathrm{c}}{ }^{\mathrm{t}}-\mathrm{P}_{\mathrm{r}}^{\mathrm{t}}\right)^{2}}{\sum_{\mathrm{t}=1}^{\mathrm{T}}\left(\mathrm{P}_{\mathrm{r}}{ }^{\mathrm{t}}-\overline{\mathrm{P}}_{\mathrm{r}}\right)^{2}} \ldots . . . .
\end{gathered}
$$

where, $P$ is the rainfall intensity, $T$ is the total number of data, $t$ is the serial number of each data point, $c$ is the compared data, and $r$ is the rain gauge data.

The data correlation analyses were conducted for 11 point rain gauge locations. The overall performance of the radar data and the satellite data were determined by the average of the $R^{2}$ and NSF values calculated for the available multiple rain gauges. Before the analysis, the data were filtered to remove outliers (e.g., negative numbers) and no record (NR) data. Such values are usually generated when the radar either malfunctions operation or needs maintenance. Only numbers equal to or greater than zero were considered.

The Mt. Merapi X-band radar data needed to be adjusted because it recorded relatively higher rainfall intensity compared to rain gauge data (evidences provided in Section 3). Because of this reason, the original radar data could not be compared with the rain gauge data directly. The tendency of spatial rainfall data overestimation at specific conditions had been discussed in other studies too $[6,14,21]$. Those studies indicated that spatial rainfall data may present spatial rainfall pattern properly. However, the recorded rainfall intensity accuracy depends on radar sensor condition. Radar data adjustments are necessary to make radar data statistically comparable to rain gauge data.

In this research, the radar data adjustments were conducted by dividing the whole set of the radar data by a series of integer, called the divisor. As an example, scenario R/15 means that the radar data were divided by 15 . In this scenario, if the original rainfall intensity recorded by radar is $75 \mathrm{~mm} / \mathrm{h}$, the adjusted rainfall value will be $5 \mathrm{~mm} / \mathrm{h}$. In statistical analysis, the divisor is equivalent to index of systematic error because it represent ratio between estimated rainfall value (radar data) and observed rainfall value (rain gauge data) $[6,14,21]$. The divisor adjusted radar recorded rainfall intensity but maintained its spatial pattern.

This research used integer divisor values that range between 5 and 20. The optimum divisor value was chosen based on the highest cumulative average of the $R^{2}$ and NSF coefficients. An $R^{2}$ value closer to 1.0 means that the data are linearly correlated. On the other hand, an NSF value closer to 1.0 means that the compared data are not only linearly correlated but also have a narrow difference in rainfall intensity.

The last step was the reliability analysis based on several rainfall types classes (Table 1). This analysis was useful in identifying which type of rainfall the radar and satellite systems were best suited for. The intervals were developed based on the BMKG rainfall classifications [9]. The analysis adopted the risk of lahar attribution approach, which was introduced by Gonda et al. [11]. Linear single value thresholds were used to determine whether or not a rainfall event had the risk of lahar. The thresholds were determined based on rainfall records that induced lahar occurrence in the past around Mt. Merapi area. The thresholds were applied to the radar and satellite rainfall data sets for comparison purposes. In the future, the thresholds will be updated, since several new rainfall and lahar records will be collected. 
Table 1. Rainfall data interval for reliability analysis.

\begin{tabular}{|c|l|}
\hline $\begin{array}{c}\text { Rainfall } \\
\text { intensity }(\boldsymbol{i}) \\
{[\mathbf{m m} / \mathbf{h}]^{*}}\end{array}$ & \multicolumn{1}{|c|}{ Category } \\
\hline $1 \leq i \leq 5$ & Light rain \\
\hline $5<i \leq 10$ & Moderate rain \\
\hline $10<i \leq 20$ & Heavy rain \\
\hline $20<i \leq 30$ & Rainfall with a risk of lahar \\
\hline $30<i \leq 60$ & Rainfall with a high risk of lahar \\
\hline $60<i \leq 110$ & Rainfall with an extremely high risk of lahar \\
\hline
\end{tabular}

${ }^{*}$ These intervals were adopted from the BMKG common rule [9]. For very heavy rainfall $(i>20 \mathrm{~mm} / \mathrm{h})$, more detailed intervals were defined from the empirical values. These values are currently agreed to be used between Balai Sabo and the MSD Research Consortium.

\section{Results and Analysis}

The $R^{2}$ value for radar-rain gauge data case was better than that of the radar-satellite data case. The $R^{2}$ value for the radar-rain gauge data comparison was 0.56 , whereas that for the radar-satellite case was just 0.02 . If the radar data higher than $110 \mathrm{~mm} / \mathrm{h}$ were omitted (max common rainfall $[11,12]$ ), the $R^{2}$ value for radar-rain gauge data comparison decreased to 0.21 . The opposite effect occurred for the radar-satellite case, where the $R^{2}$ value increased to 0.04 . On the other hand, the NSF values indicated that both of the radar-rain gauge and radar-satellite data are disproportional, as the NSF values are -981 and -958 , respectively. When the higher than $110 \mathrm{~mm} / \mathrm{h}$ data were omitted, the NSF values decreased substantially to -237 and -34 , respectively.

The Nash-Sutcliffe efficiency values increased when the radar data values were proportionally divided by integer divisors. All the values for R/15 in Fig. 3(a) are out of the plot area (i.e., less than zero) except for Sukorini. Moreover, the optimum integer divisor for radar-rain gauge data comparison was 16 , as most of the NSF values were less than zero for divisors less than 16 (Fig. 3(b)). In contrast, the NSF values were nearly constant if the divisors were 17, 18, and 19. The NSF values of these divisors were distinguishably less than the NSF value if the divisor was 16 . These patterns were also obtained when radar data were compared with satellite data. However, the rank of the NSF values among several point locations were different, specifically between the radar-rain gauge and radar-satellite comparisons. For example, the Talun point radar-rain gauge NSF was worse compared to the Talun point radar-satellite NSF, while the situation for Sopalan point was the opposite.

After the radar data adjustment was conducted, it was found that the radar data and the satellite data can capture $79 \%$ and $72 \%$ of the rainfall occurrences at certain point locations, respectively. It was also found that, on $6-16 \%$ of the occasions, both the radar and satellite detected rainfall but none was recorded by the rain gauges. Another interesting finding is that the satellite data started to detect rainfall occurrence earlier than the radar and rain
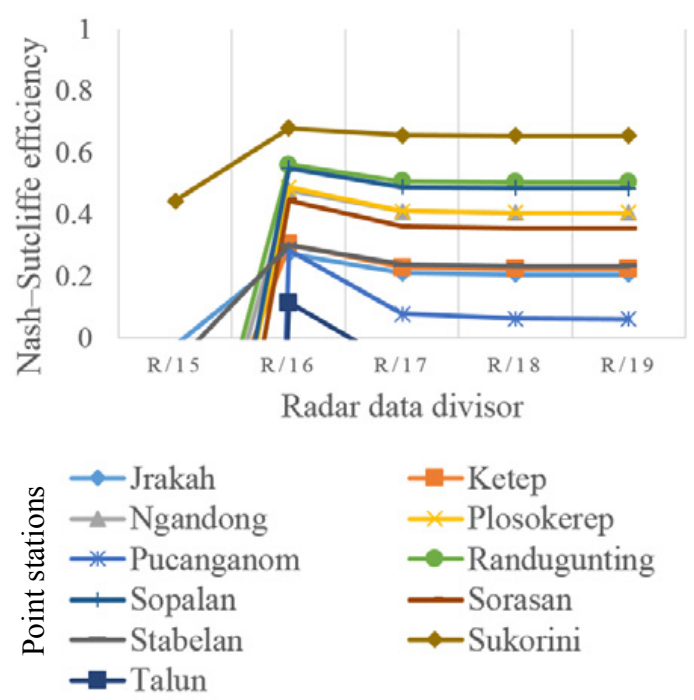

(a) Radar-rain gauge data comparison

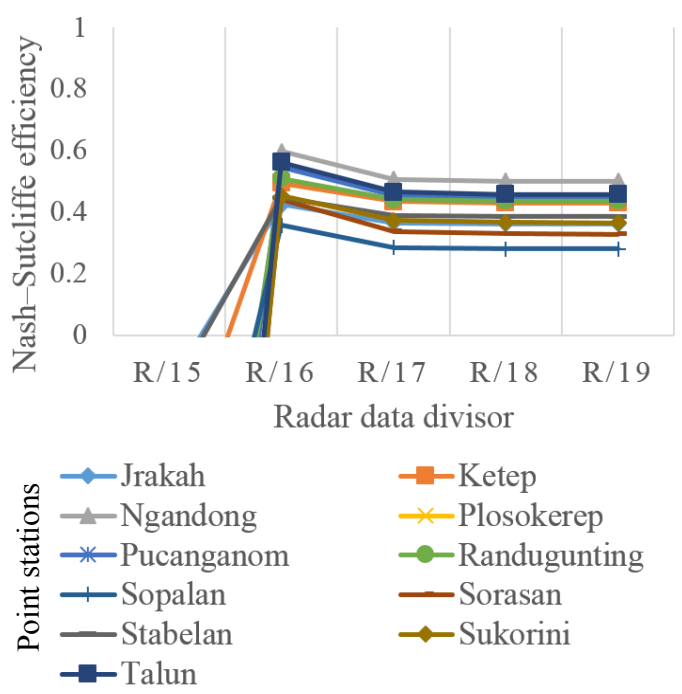

(b) Radar-satellite data comparison

Fig. 3. Radar data correlation pattern among integer divisors compared to rain gauge data (a) and satellite data (b).

gauge data. For instance, based on the extreme rainfall event case (Fig. 4), the satellite recorded rainfall about five hours earlier than the radar and the rain gauge did. The satellite also recorded some data during the peak rainfall as the rain gauge station did, whereas the radar was off for five hours at that time (Radar NR). The satellite data captured the connection between the first (time 5) and second (time 10) rainfall events as an interrelated series of rainfall events, while the radar and the rain gauge did not. Unfortunately, the satellite rainfall data at that point were generally low (less than $20 \mathrm{~mm} / \mathrm{h}$ ).

It was found that the radar captured $22-49 \%$ of the rainfall events with accurate intensity in comparison to the rain gauge data, whereas the satellite captured only 9-34\%. These percentages were even higher when the overestimations were included. This approach is sometimes acceptable by considering that at least the radar or the satellite can capture the rainfall occurrence, albeit with 


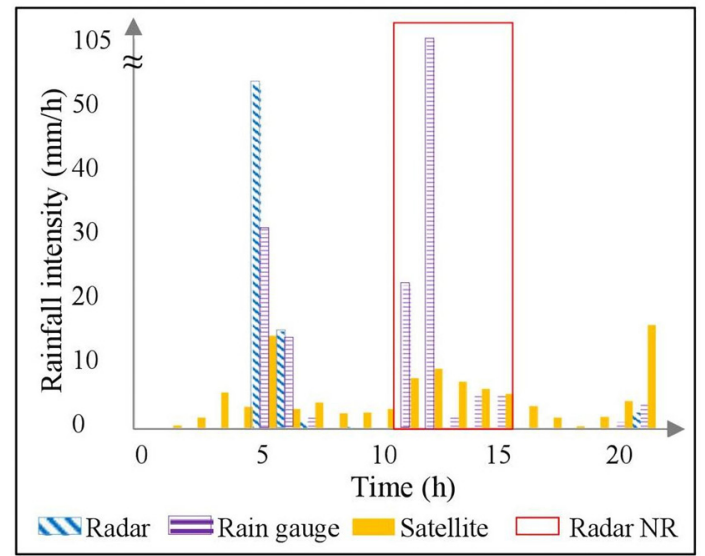

Fig. 4. Rainfall event series example on the March 25, 2017 event at Sukorini point rain gauge station.

a slightly higher intensity. Fig. 5 shows that the radar data performed well in capturing rainfall events that have high and extremely high risks of lahar. Overall, the adjusted radar data had a tendency to underestimate the rain gauge data. Even all of the rain gauge rainfall events with extreme risk of lahar intensity were underestimated by the radar. Moreover, the statistical analysis spotted that the radar data had a wider range of values compared to the other rainfall data, as the standard deviation of the radar data were quite wide (Fig. 6). The radar data could mostly cover the deviation range of all rain gauge data across the rainfall classes. Though, in the class of rainfall with extremely high risk of lahar, the radar data failed to capture the rain gauge-recorded rainfall data. In the class of rainfall with extremely high risk of lahar, the radar data average was lower than the lower standard deviation of the rain gauge-recorded rainfall.

In contrast, the satellite data were quite good for the interpretation of drizzling and light rain, with a big tendency of overestimation. The capability of the satellite data to capture the rainfall events that trigger lahar $(>20 \mathrm{~mm} / \mathrm{h})$ were mostly less than $10 \%$. The satellite data had a large deviation of rainfall intensity compared to the rain gauge data (Fig. 6). It was clear that the satellite failed to capture high rainfall intensities. Moreover, the satellite records were complete and coherent throughout the analysis period.

\section{Discussions}

Based on the analyses and results described in Section 3 , it can be summarized that the installed radar can give reliable rainfall information for a lahar early warning system with accuracies of 22-49\% compared to rain gauges. The reliability test had shown that the radar data represent a similar rainfall pattern compared to the rain gauges that were placed in mountainous areas with risk of lahar. However, the radar performances were diverse among the different rainfall types. These results are consistent with other research related to extreme rainfall in the mountainous areas of East Kanto Region, Japan [21].

The recorded rainfall intensity from the radar needs adjustment (in this case, R/16 as described in Section 3), as the rainfall radar intensity is averaged over a single radar grid. In contrast, the rain gauge data represent rainfall at a single point location. The other reason is that the radar basically captures the rainfall condition at a certain height above the ground, while the rain gauge is on the ground. Thus, the radar can capture rainfall event in aerial perspectives. Therefore, the radar data represents a better rainfall pattern than that provided by data from the 11 rain gauges that were spread across the study area.

It must be acknowledged that the use of rain gauge data as a benchmark for the reliability analysis involved the uncertainty of the rain gauge measurement practice. This is the limitation for radar data reliability test in many other studies too $[11,12]$. As the owner of the data, Balai Sabo had taken some actions to minimize rain gauge data uncertainty. Specifically, the institution had removed the outliers (e.g., rain intensity $>110 \mathrm{~mm} / \mathrm{h}$ ) before publishing the data. Furthermore, Balai Sabo always checks its rain gauge conditions every three months and conducts a special check if the rain gauge is broken.

The radar performs well in capturing both rain and norain conditions compared to the rain gauges. Only on a few occasions did the radar measure some rainfalls when there was no rainfall recorded by the rain gauges. These situation were occurred in drizzling and light rain events. The existence of no-record and no-rain conditions could also be confirmed by referring to the satellite data, which had the most complete data during the measurement period.

Another interesting finding is that the radar performs well in heavy rain cases while the satellite data are good at representing light rain cases. The closest indication is that the rainfall data have narrower grid size than the satellite data. The satellite data gave a wider view of the rainfall pattern across the area, which gave a clearer determination of rain or no-rain conditions. Instead, it would be easier for the radar to capture medium and high rainfall intensities, which may produce faster and more detailed rainfall distribution patterns of the studied area. Unfortunately, the analysis indicates that the current radar has a limitation in detecting extreme rainfalls. The radar underestimated rainfall intensities with extremely high risk of lahar. It might be because the radar was averaging rainfall intensities in each radar spatial grid.

This research did not address rainfall duration and aerial distribution reliability test of the radar data. The inconsistent continuities of rain gauge data among the 11 locations did not allow a duration reliability test to be performed based on the multi-station approach. In addition, the rain gauge data discontinuity did not allow aerial test to be conducted because the number of rain gauges that were used to represent rainfall spatial distribution were differ in each period. The operating period of the radar must be improved, as there were still so many NR data. The aforementioned tests are feasible if there are continuous rain gauges and radar data records in the study area. 


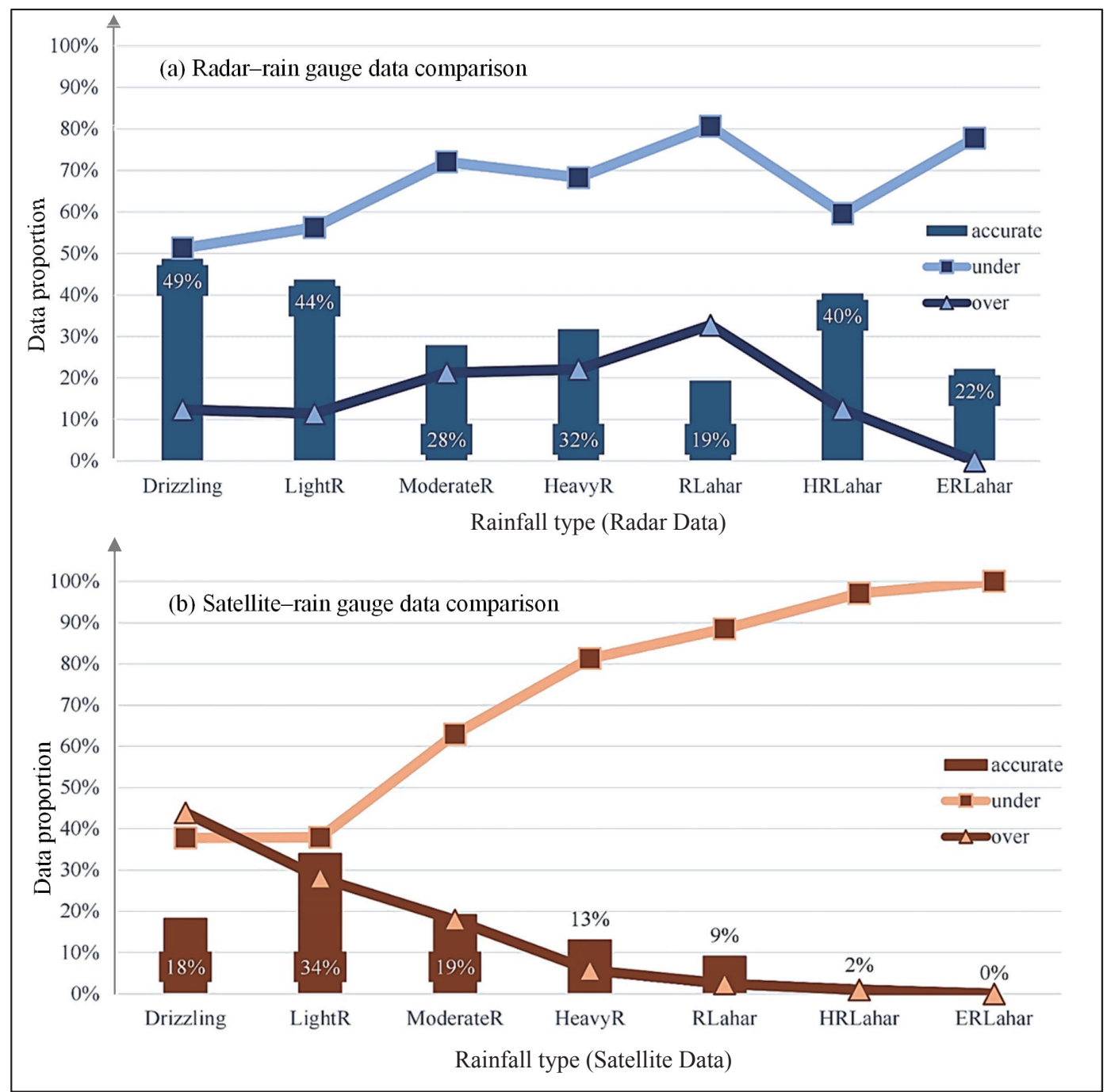

The rainfall types are based on the rainfall classification ranges in Table 1. The upper (a) shows radar-rain gauge data comparison. The lower (b) represents satellite-rain gauge data comparison. The bars indicate the percentage of data that roughly match with the rain gauge data. The square markers denote the percentage of data that underestimate the rain gauge data, while the triangle markers represent the percentage of data that overestimate the rain gauge data.

Fig. 5. Proportion of adjusted radar data and satellite data compared to rain gauge data classifications.

For further application, the radar data can be presented in conjunction with the available weather information, which uses the satellite data (see Fig. 7 in Appendix A). The proposed point-based visulalization platform (Fig. 8 in Appendix B) will provide more specific rainfall condition at a desired location, which is extracted from the adjusted rainfall radar data. The proposed platform will combine the strengths of both aerial satellite data and radar data.

\section{Conclusions}

The research has resulted in the conclusion that radar data distribution and corresponding rain gauge (ground) data distribution can be used as near real-time rainfall information inputs for the Mt. Merapi Early Warning System. This conclusion is supported by the fact that, based on January 2017-March 2018 data, the $R^{2}$ between the radar and rain gauge measured data is 0.56 , whereas the NSF is 0.41 . The radar can capture rainfall within a lag time of five minutes, whereas not all the rain gauges can transfer rainfall data at this frequency through the telemetry system. The satellite rainfall monitoring system also cannot perform as well as the radar. However, the radar data still needs to be adjusted periodically to have satisfactory representation of the rainfall distribution. The radar can capture about $79 \%$ of the rainfall occurrence, with about $6 \%$ of cases when the rainfalls are erroneously detected by radar. The radar performance in detecting drizzling and light rain types are quite good (55\% of cases), although the satellite data performs slightly better $(60 \%$ of cases). The radar performance in detecting heavy rainfall with the risk of lahar is also acceptable (40-50\% of cases). Interestingly, the radar seems to underestimate the intensity of extreme rainfall events. Calibration and further comparison based on rainfall duration and aerial distribution are necessary in future studies. 


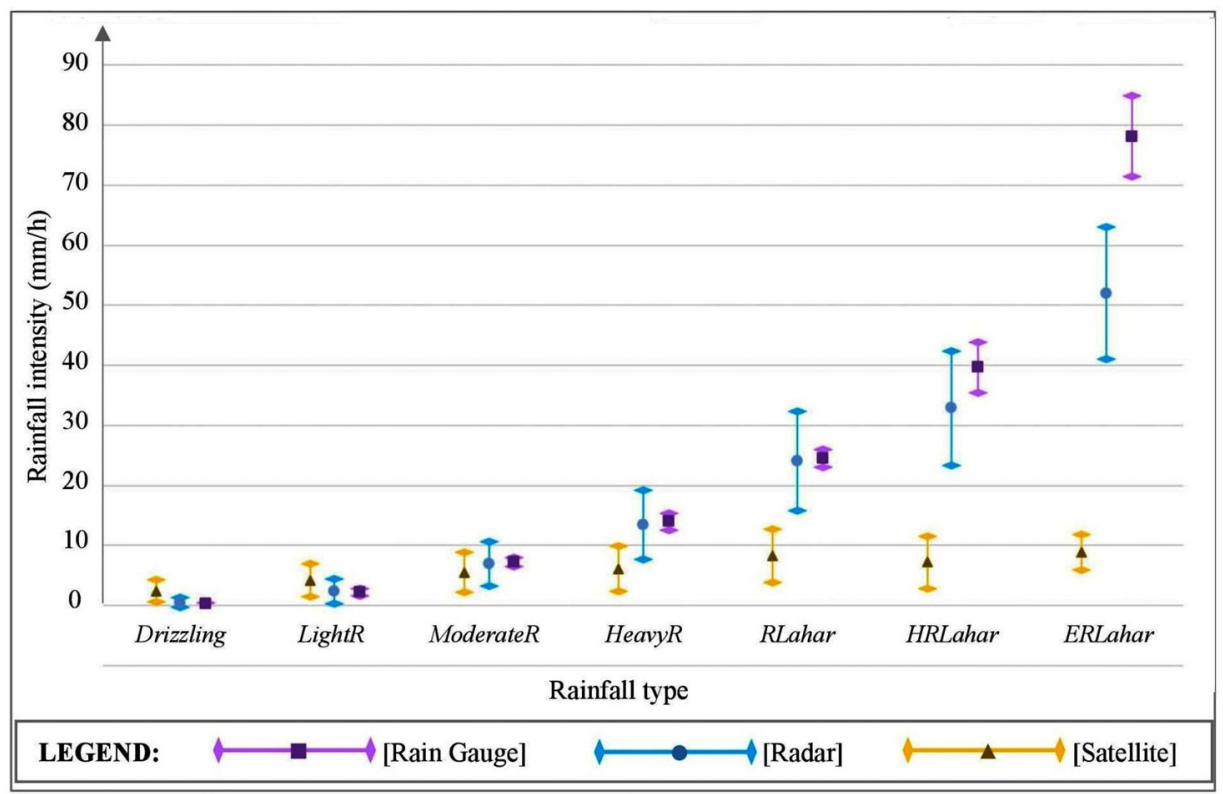

Fig. 6. Comparison of rainfall data ranges from several sources.

\section{Acknowledgements}

This research is supported by the SATREPS Project, a joint cooperation of the Japanese and Indonesian governments. The authors deeply appreciate Prof. D. Legono (UGM), Prof. Adam P. Rahardjo (UGM), Prof. Iguchi Masato (Kyoto University), Prof. em. Kuniaki Miyamoto, Prof. Satoru Oishi (Kobe University), Mr. Kasbani (PVMBG), Mr. Eko Winar Irianto (PUSAIR), Mr. Dwi Kristianto (Balai Sabo), and all colleagues that made priceless contributions to this research. Special thanks go to LPDP (Indonesian Endowment Fund for Education Agency) for supporting the first author in coordinating the writing of this paper from the University of Leeds, UK.

\section{References:}

[1] F. Lavigne et al., "Instrumental lahar monitoring at Merapi Volcano, Central Java, Indonesia," J. Volcanol. Geotherm. Res., Vol.100, Nos.1-4, pp. 457-478, 2000.

[2] S. S. Putra, C. Hassan, and S. Hariyadi, "Hot pyroclastic deposit as lahar resistor: a case study of Gendol River after the Mt. Merapi 2010 eruption," Monitoring, Simulation, Prevention and Remediation of Dense and Debris Flows IV, pp. 97-109, 2012.

[3] R. Putratama, "Peresmian Operasional Radar Cuaca Di Stasiun Meteorologi Klas III Frans Seda, Maumere, NTT,” Berita Badan Meteorologi, Klimatologi, dan Geofisika, 2017. http://www.bmkg.go.id/ berita/?p=6958\&lang=ID [accessed May 18, 2018]

[4] M. D. Yamanaka et al., "HARIMAU Radar-Profiler Network over the Indonesian Maritime Continent: A GEOSS Early Achievement for Hydrological Cycle and Disaster Prevention,” J. Disaster Res. Vol.3, No.1, pp. 78-88, 2008.

[5] S. P. C., T. Nakatani, and R. Misumi, "Hydrological Simulation of Small River Basins in Northern Kyushu, Japan, During the Extreme Rainfall Event of July 5-6, 2017," J. Disaster Res., Vol.13, No.2, pp. 396-409, 2018.

[6] Y. Yonese, A. Kawamura, H. Amaguchi, and A. Tonotsuka, "Study on the precision of 1-minute X-Band MP radar rainfall data in a small urban watershed," Int. J. Sustain. Dev. Plan., Vol.13, No.4, pp. 614-625, 2018.

[7] Y. Sugihara, S. Imagama, N. Matsunaga, and Y. Hisada, "Numerical Experiments on Spatially Averaged Precipitation in Heavy Rainfall Event Using the WRF Model," J. Disaster Res., Vol.10, No.3, pp. 436-447, 2015.

[8] L. J. Cobar, D. Legono, and K. Miyamoto, "Modeling of Information Flow for Early Warning in Mount Merapi Area, Indonesia," J. Disaster Res., Vol.11, No.1, pp. 60-71, 2016.
[9] BMKG and BIG, "Citra Radar Cuaca Mozaic Indonesia Terkini - Yogyakarta," Badan Meteorologi, Klimatologi, dan Geofisika in cooperation with Badan Informasi Geospasial, 2018. https://www. bmkg.go.id/cuaca/citra-radar.bmkg [accessed May 21, 2018]

[10] Evan and Golbez, "Indonesia provinces blank," Wikimedia Commons, 2009. https://commons.wikimedia.org/wiki/File:Indonesia provinces_blank.png [accessed May 21, 2018]

[11] Y. Gonda, D. Legono, B. Sukatja, and U. B. Santosa, "Debris flows and flash floods in the Putih River after the 2010 eruption of Mt. Merapi, Indonesia,” Int. J. Eros. Control Eng., Vol.7, No.2, pp. 63-68, 2014.

[12] E. de Bélizal et al., "Rain-triggered lahars following the 2010 eruption of Merapi volcano, Indonesia: A major risk," J. Volcanol. Geotherm. Res., Vol.261, pp. 330-347, 2013.

[13] H. Uyeda, "Mesoscale Precipitation Systems Along the Meiyu/Baiu Front and Future Expectation for Research Radar and Weather Radar Network," J. Disaster Res., Vol.3, No.1, pp. 61-68, 2008.

[14] M. Maki et al., "Preliminary Results of Weather Radar Observations of Sakurajima Volcanic Smoke," J. Disaster Res., Vol.11, No.1, pp. 15-30, 2016.

[15] M. Syarifuddin, S. Oishi, D. Legono, R. I. Hapsari, and M. Iguchi, "Integrating X-MP radar data to estimate rainfall induced debris flow in the Merapi volcanic area," Adv. Water Resour., Vol.110, pp. 249-262, 2017.

[16] FURUNO, "FURUNO's meteorological monitoring and analysing system," Furuno System Solution, 2014. http://www.furuno.com/ en/systems/meteorological-monitoring/ [accessed May 21, 2018 ]

[17] S. Oishi, M. Iida, M. Muranishi, M. Ogawa, R. I. Hapsari, and M. Iguchi, "Mechanism of Volcanic Tephra Falling Detected by X-Band Multi-Parameter Radar," J. Disaster Res., Vol.11, No.1, pp. 43-52, 2016.

[18] G. Huffman, "GPM IMERG Final Precipitation L3 Half Hourly 0.1 degree x 0.1 degree V05," Greenbelt, MD, Goddard Earth Sciences Data and Information Services Center (GES DISC), 2018.

[19] G. Skofronick-Jackson et al., "The Global Precipitation Measurement (GPM) Mission for Science and Society," Bull. Am. Meteorol Soc., Vol.98, No.8, pp. 1679-1695, 2017.

[20] S. S. Putra and B. Neilzon, "River bed stabilization structures placement determination based on satelite data," The 5th HATHI Int. Seminar on Water Resilience in a Changing World, 2016, p. 894 , 2016.

[21] S. P. C. et al., "Accuracy of Quantitative Precipitation Estimation Using Operational Weather Radars: A Case Study of Heavy Rainfall on 9-10 September 2015 in the East Kanto Region, Japan," J. Disaster Res., Vol.11, No.5, pp. 1003-1016, 2016.

[22] M. L. M. Scheel, M. Rohrer, C. Huggel, D. Santos Villar, E. Silvestre, and G. J. Huffman, "Evaluation of TRMM Multi-satellite Precipitation Analysis (TMPA) performance in the Central Andes region and its dependency on spatial and temporal resolution," Hydrology and Earth System Sciences Discussions, Vol.7, No.5. pp. 8545-8586, 2010 


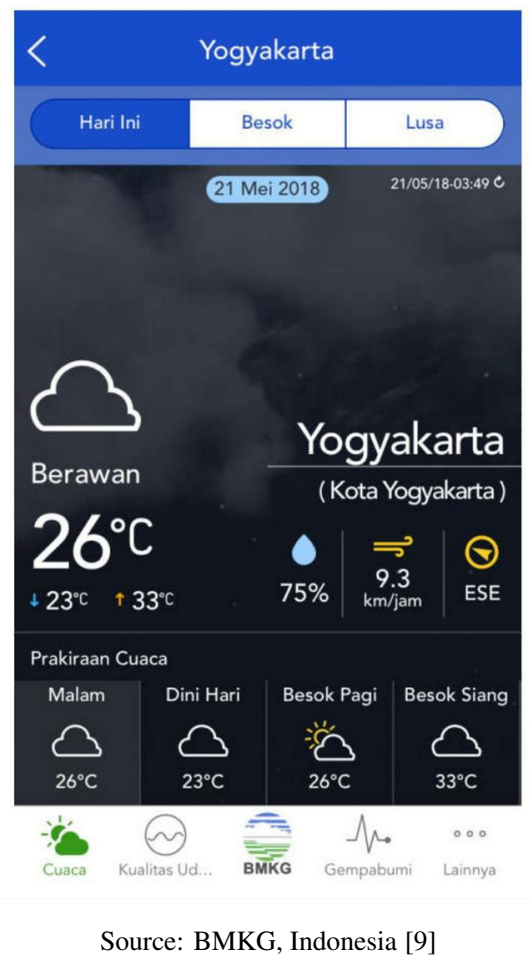

Fig. 7. Screen shot of the Info BMKG app.

\section{Appendix A. Official Rainfall Mobile Applica- tion}

The Info BMKG app (Fig. 7) is rain forecast application used by the local communities.

\section{Appendix B. Point-Based Rainfall Webpage}

This system allows users to enquire about the rainfall condition for a specific location (Fig. 8).

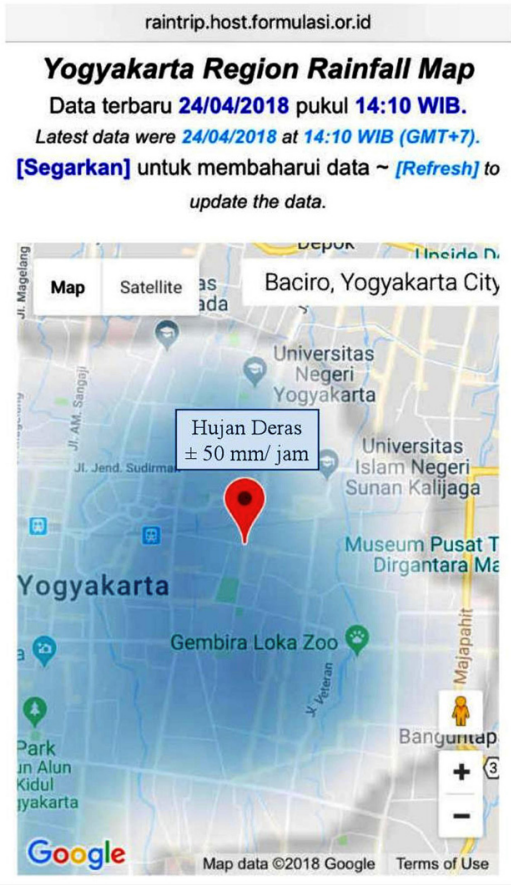

Source: SATREPS SDIS Team (Yogyakarta Cyclone, 24 April 2018)

Fig. 8. Screen shot of the point-based rainfall mobile app.

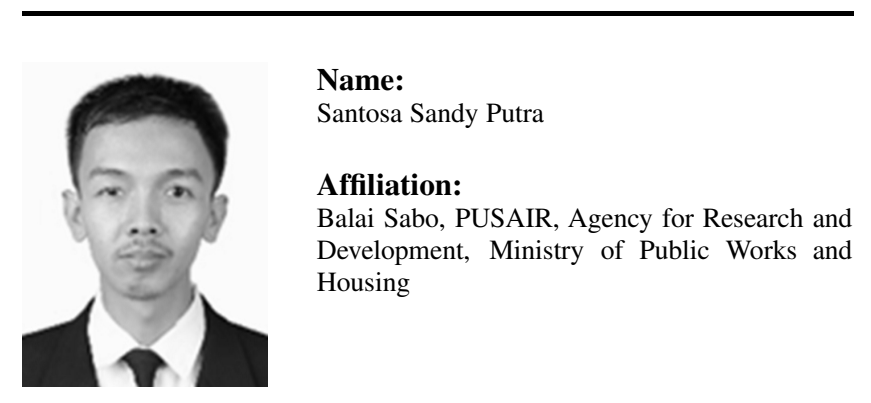

Address:

Balai Sabo, Sopalan, Maguwoharjo, Yogyakarta 55282, Indonesia Brief Career:

2008- Research Assistant, Universitas Gadjah Mada 2009- Engineer, Balai Sabo, Ministry of Public Works 2018- Ph.D. Student, University of Leeds

Selected Publications:

- S. S. Putra, G. A. Corzo Perez, S. van der Pijl, H. Kernkamp, A. van Dam and D. P. Solomatine, "Measuring domain decomposition effect in estuary model parallelization using high performance computer," 2014 6th Int. Conf. on Information Technology and Electrical Engineering (ICITEE), Yogyakarta, pp. 1-6, 2014.

Academic Societies \& Scientific Organizations:

- Indonesian Association of Hydraulic Engineers (HATHI)

- Indonesian Researcher Society (HIMPENINDO)

- Indonesian Association of Disaster Experts (IABI)

- Institution of Engineers Indonesia (PII) 


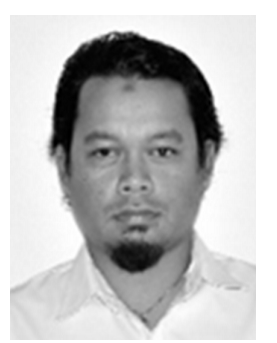

Name:

Banata Wachid Ridwan

\section{Affiliation:}

Balai Sabo, PUSAIR, Agency for Research and Development, Ministry of Public Works and Housing

\section{Address:}

Balai Sabo, Sopalan, Maguwoharjo, Yogyakarta 55282, Indonesia

Brief Career:

2011- Technical Staff, Ministry of Public Works

Selected Publications:

- S. S. Putra and B. W. Ridwan, "Interconnected ponds operation for flood hazard distribution," The 5th Int. Symposium on Earth hazard and Disaster Mitigation: The Annual Symposium on Earthquake and Related Geohazard Research for Disaster Risk Reduction, Bandung, 2016.

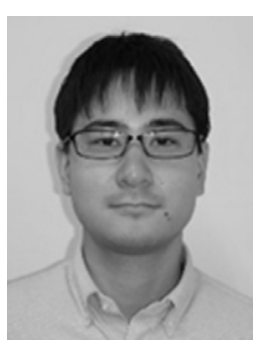

\section{Name:}

Kazuki Yamanoi

\section{Affiliation:}

RIKEN Center for Computational Science

\section{Address:}

7-1-26 Minatojima-minami-machi, Chuo-ku, Kobe 650-0047, Japan Brief Career:

2017- Postdoctoral Researcher, Ministry of Public Works, Indonesia 2018- Postdoctoral Researcher, RIKEN Center for Computational Science Selected Publications:

- K. Yamanoi and M. Fujita, "Development of a combined model of sediment production, supply and transport, and its application to a mountainous basin,” J. of JSCE, Vol.3, No.1, pp. 224-229, 2015.

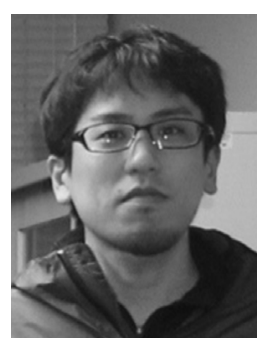

Name:

Makoto Shimomura

\section{Affiliation:}

Sakurajima Volcano Research Center, Disaster Prevention Research Institute, Kyoto University

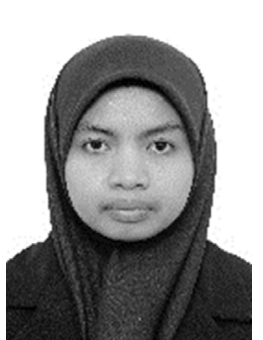

\section{Name:}

Sulistiyani

\section{Affiliation:}

Balai Penyelidikan dan Pengembangan Teknologi Kebencanaan Geologi, Center for Volcanology and Geological Hazard Mitigation, Geological Agency

Address:

Jl. Cendana No.15, Yogyakarta, 55166, Indonesia

Brief Career:

2015- Geological Researcher, Geological Agency, Indonesia

Selected Publications:

- M. Shimomura, M. Iguchi, S. Sulistiyani, A. B. Santoso, I. G. M. A. Nandaka, and K. Miyamoto, "Quasi-real time pyroclastic flow hazard mapping system at Mt. Merapi," EGU General Assembly Conf. Abstracts, Vol.19, 9878, pp. 1-6, 2014.

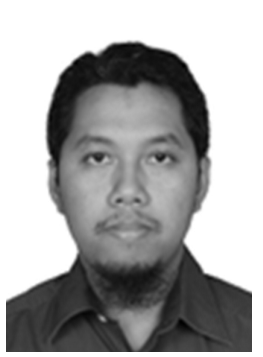

\section{Name:}

Dicky Hadiyuwono

\section{Affiliation:}

Hydraulic Laboratory, Department of Civil and Environmental Engineering, Universitas Gadjah Mada

Address:

Jalan Grafika No.2 Yogyakarta, Indonesia

Brief Career:

2011- Researcher/Instrument Engineer, University of Gadjah Mada

\section{Address:}

1722-19 Yokoyama, Sakurajima, Kagoshima 891-1419, Japan

\section{Brief Career:}

2014- Research Associate, University of Tsukuba

2018- Specially Appointed Researcher, Kyoto University

Selected Publications:

- M. Shimomura, "Numerical Analysis of High-Performance Lithium-Ion and Lead-Acid Batteries with Capacity Fade for an Off-Grid Residential PV System,” ASCE J. Energy Eng., Vol.142, No.1, 04015006, 2016. 